Bот. GAZ. 139(4):490-498. 1978.

(C) 1978 by The University of Chicago. 0006-8071/78/3904-0003\$00.88

\title{
CUTICULAR FEATURES AND EPIDERMAL PATTERNS IN THE GENUS ARAUCARIA DE JUSSIEU
}

\author{
RUTH A. STOCKEY AND THOMAS N. TAYLOR
}

Department of Botany, University of Alberta, Edmonton, Alberta, Canada T6G 2E9; and Department of Botany, Ohio State University, Columbus, Ohio 43210

\begin{abstract}
The cuticular organization and epidermal features of leaves from the four sections of the genus Araucaria, growing under similar environmental conditions, were studied by scanning electron microscopy. Cuticles from these extant species and the Jurassic fossil Araucarites santaecrucis were compared by rubber replicas and examination of the fossil leaf surfaces. Two distinct groups of araucarian leaves are distinguished by cuticular features. The Columbea-Bunya species have regular stomatal rows with polar cells always oriented in the same direction, four to five subsidiary cells, and a granular inner cuticle surface on both epidermal and subsidiary cells. The Eutacta-Intermedia species have four to seven subsidiary cells with thin cuticular flanges between guard cells and subsidiary cells, a smooth inner cuticular surface on both epidermal and subsidiary cells, and thinner intercellular flanges on epidermal cell walls. Epidermal features of araucarian leaves appear to be taxonomically useful at the section level.
\end{abstract}

\section{Introduction}

The family Araucariaceae has been regarded as one of the most primitive of the Coniferales with a long geologic history in both the Northern and Southern Hemispheres. It contains only two genera, Araucaria de Jussieu and Agathis Salisbury. The genus Araucaria is a group of Southern Hemisphere conifers with a very restricted distribution. DE LAUBENFELS (1972) recognizes 14 of the 21 species endemic to the island of New Caledonia; two species are restricted to South America, three to New Guinea, and one to Australia (WiLde and EAmes 1952). The genus is divided into the sections Columbea, Eutacta, Intermedia, and Bunya, each with a distinctive leaf form (WILDE and EAMEs 1952). Leaves of living species were studied with the light microscope by FLORIN (1931) and CoOKSON and Duigan (1951). Fossil araucarians were investigated mainly by Kendall (1949), Cookson and Duigan (1951), Menendez and Caccavari (1966), Pant and Srivastava (1968), and Bose (1975).

This investigation characterizes the cuticular features and epidermal patterns of leaves from each of the four sections of the genus with scanning electron microscopy. Features of these leaves are compared with those of the Jurassic fossil Araucarites santaecrucis Calder, the foliage type associated with the ovulate cone Araucaria mirabilis (Speg.) Calder at the Cerro Cuadrado Petrified Forest in Patagonia.

\section{Material and methods}

Fresh leaves from four sections of the genus including one of the two Columbea species, Araucaria angustifolia (Bertolini) O. Kuntze; one of the three Intermedia species, A. klinkii Lauterbach; the only extant Bunya species, A. bidwillii Hooker (WildE and EAmes 1952); and one of the 15 Eutacta species

Manuscript received May 1978; revised manuscript received August 1978.
(DE Laubenfels 1972), A. cunninghamii Aiton ex Lambert, were prepared for study. Leaves were collected at the Imbil Forestry Research Station in Southern Queensland, Australia, in January 1977 from trees growing under similar environmental conditions. Cuticles were prepared by cutting the leaves longitudinally to expose the mesophyll and immersing them in $20 \%$ chromium trioxide solution for 6, 18, and $24 \mathrm{~h}$ (Alvin and Boulter 1974). The 24-h treatment produced the cleanest cuticle preparations since some leaves were rather thick and contained many fibers. Cuticles were washed in water, air-dried, and mounted on stubs with silver conductive paint. Both surfaces were examined by scanning electron microscopy. Some cuticles were prepared according to standard schedules for examination by transmitted light. Fresh leaves from these four species were also dehydrated and embedded in glycol methacrylate (FEDER and O'BRIEN 1968; Robison and Miller 1975) for sectioning and light microscope examination.

Rubber replicas were made of the surfaces of Araucarites santaecrucis leaves with KERR Permlastic dental rubber (KERR Sybron Corp., Romulus, Michigan 48174), similar to a technique by Watson and Alvin (1976). The light-bodied base and catalyst mixture were applied first to infiltrate the small pores, using a dissecting needle to puncture and eliminate bubbles from the final cast. After drying, the heavy-bodied base and catalyst were used as a second coat to hold the mold in shape. Replicas were dried thoroughly for $24 \mathrm{~h}$ before coating to avoid out-gassing of the catalyst mixture in the coater. The inner surfaces of these replicas were examined and their structure compared to the inner cuticular surface of living araucarian species. Since there are no cuticular remains on the fossils, the replicas represent the actual cuticle in places where epidermal cells are preserved. The outer surfaces of 
the specimens were sputter coated with gold and examined with a Hitachi S-500 Scanning Electron Microscope at $20 \mathrm{kV}$.

\section{Results}

Araucaria angustifolia, Section Columbea.The mature leaves are broad, leathery, and imbricate with acute tips. The cuticle is thick over the entire leaf surface, especially surrounding the subsidiary cells (fig. 1). Stomata occur in regular rows on both the abaxial and adaxial surfaces and are usually covered by a waxy cuticular plug (fig. 3 ). When this plug is mechanically removed (fig. 6), the sunken nature of stomata becomes visible with three levels of cuticular thickening. The cuticle covering the subsidiary cells is slightly more sunken than that of the surrounding epidermis; cuticle surrounding the guard cells is further depressed (fig. 6).

The inner cuticle surface reveals the most information regarding stomatal apparatus and epidermal patterns (figs. 1, 2, 4, 5). Stomata are arranged in regular rows with the polar cells always oriented in the same direction (fig. 2). Subsidiary cell number is commonly four, rarely five. The fifth cell usually results from the division of one of the polar cells (fig. 1), but some lateral subsidiary cells occasionally appear to have undergone division. Intercellular flanges (Boulter 1971) on epidermal cells (extensions of the inner surface of the cuticle produced at the boundary of juxtaposed epidermal cells) are steep in this species when compared to those of other conifers. Flanges are thick and become pitted after $24 \mathrm{~h}$ in chromium trioxide (figs. 1, 5). Six- and 18-h treatments generally failed to remove the thick bands of hypodermal fibers. Epidermal cell walls appear straight to slightly sinuous in outline (fig. 2). The cuticle on the surfaces of the epidermal cells is granular in texture (fig. 5), similar to that reported in the Taxodiaceae (Alvin and Boulter 1974) but unlike that of other conifers.

The cuticle in the region of the stomatal apparatus is usually regarded as one of the most important parts taxonomically. Features present here are not distinct under the light microscope due to overlap of cuticular material and the complex pattern that it forms. The guard cells are situated at the hypodermal level, unlike those in Tsuga heterophylla (Rafinesque) Sargent in which the guard cells lie just below the surface, but they are similar in position to those in the Miocene fossil Cryptomeria rhenana Kilpper and Sequoiadendron giganteum (Lindley) Buchholz (Boulter 1971). The cuticle on the subsidiary cells is depressed and shaped like an open umbrella (fig. 1), as in S. giganteum (Boulter 1971). The surface of the cuticle on subsidiary cells is granular. The flanges of cuticle between the guard cells and subsidiary cells are thick and irregular in outline (figs. 1, 4). A ridge of cuticular tissue occurs in the aperture between the guard cells in A. angusti- folia which has slight polar extensions. The surface ornamentation on the guard cell walls has several rounded pits represented by small rounded bumps of cuticular material (fig. 4). There are no striations or folds similar to those that have been described in other conifer taxa such as Pinus peuce Grisebach or Sequoiadendron (Boulter 1971).

Araucaria klinkit, Section Intermedia.-These leaves are the largest known for the genus. Mature leaves reach $12 \mathrm{~cm}$ long and are thin, flat, and often imbricate. Cuticle from this species is thick, and stomata occur in regular rows on both surfaces. Externally, stomata have cuticular plugs similar to other araucarian species (fig. 9). Removal of these plugs reveals three levels of cuticular thickening similar to those of $A$. angustifolia (fig. 6). No raised areas or Florin rings have been observed.

The inner cuticle surface has regularly arranged stomata, most with the polar cells oriented in one direction. A few stomata have slightly skewed guard cells with the ridge of cuticle separating them aligned with one of the ridges dividing subsidiary cells (fig. 8 ). Four is the most common number of subsidiary cells. Five subsidiary cells do, however, occur with higher frequency in this taxon than any other araucarians examined; six to seven subsidiary cells occur in lesser frequencies. Divisions of these subsidiary cells appear not to be the result of the polar cell division, but rather lateral cell division.

An 18-h chromium trioxide treatment of the leaves reveals cellular debris which has not been removed (fig. 10). The leaves of $A$. klinkii have scattered sclereids and lack the massive bundles of fibers that occur in Sections Bunya and Columbea (fig. 18). Flanges on epidermal cells are very steep and usually unpitted. Epidermal cell walls appear slightly wavy or undulating with very steep buttresses. At the bases of these buttresses are prominent ridges or striations similar to those in some of the Taxodiaceae (Boulter 1971). Cell surfaces are entirely smooth and lack a granular texture (fig. 7).

The guard cells are deeply sunken to the hypodermal level. The umbrella-shaped cuticle covering subsidiary cells is unusually thick in this species (fig. 7), especially between subsidiary and epidermal cells. The surface of the subsidiary cell cuticle is smooth, as on the epidermal cells of this species. Flanges of cuticle between guard and subsidiary cells are thin when compared to other araucarian species, especially on the lateral subsidiary cells (fig. 7). Surface ornamentation on guard cell walls is reticulate with some scattered, rounded bumps of material as in A. angustifolia (fig. 11). The ridge of cuticle between guard cells is similar to that in $A$. angustifolia (figs. 7, 11).

Araucaria bidwillit, Section Bunya.-Leaves from mature trees exhibit two distinct morphological types and vary from small, broadly based, imbricate forms in a tight helix to larger, broad, and flattened 

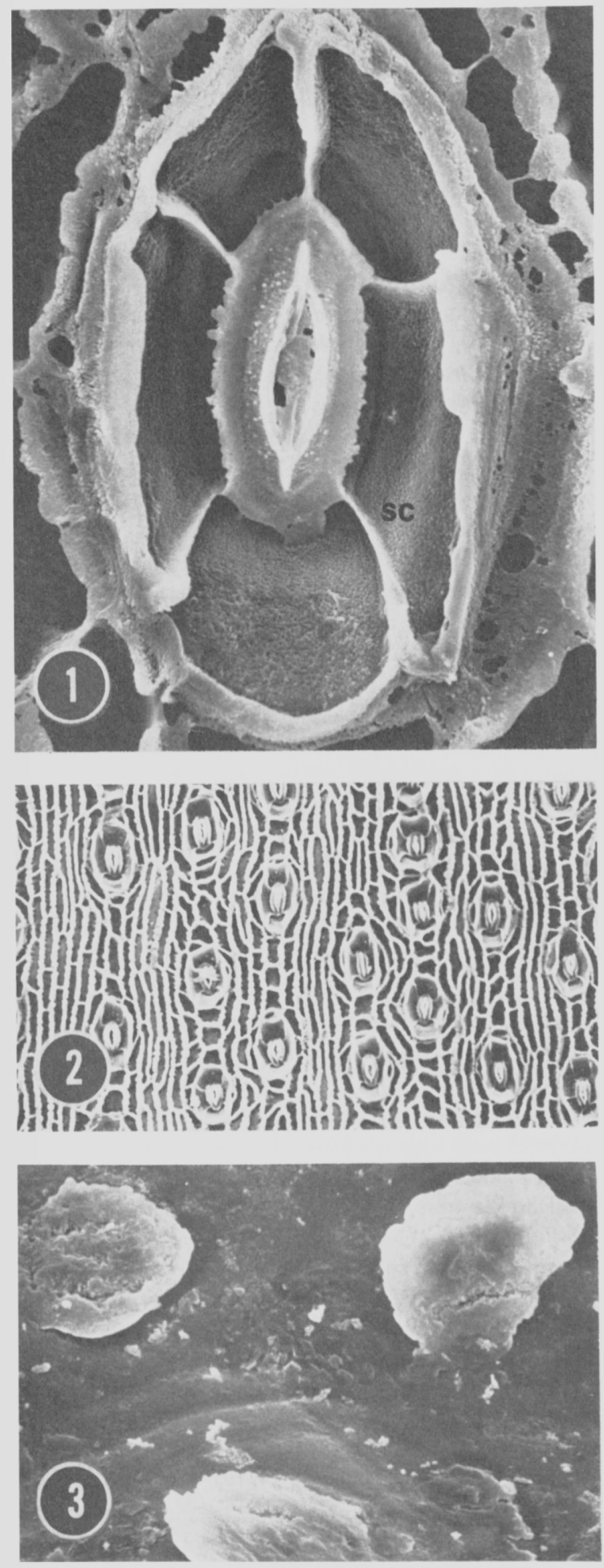
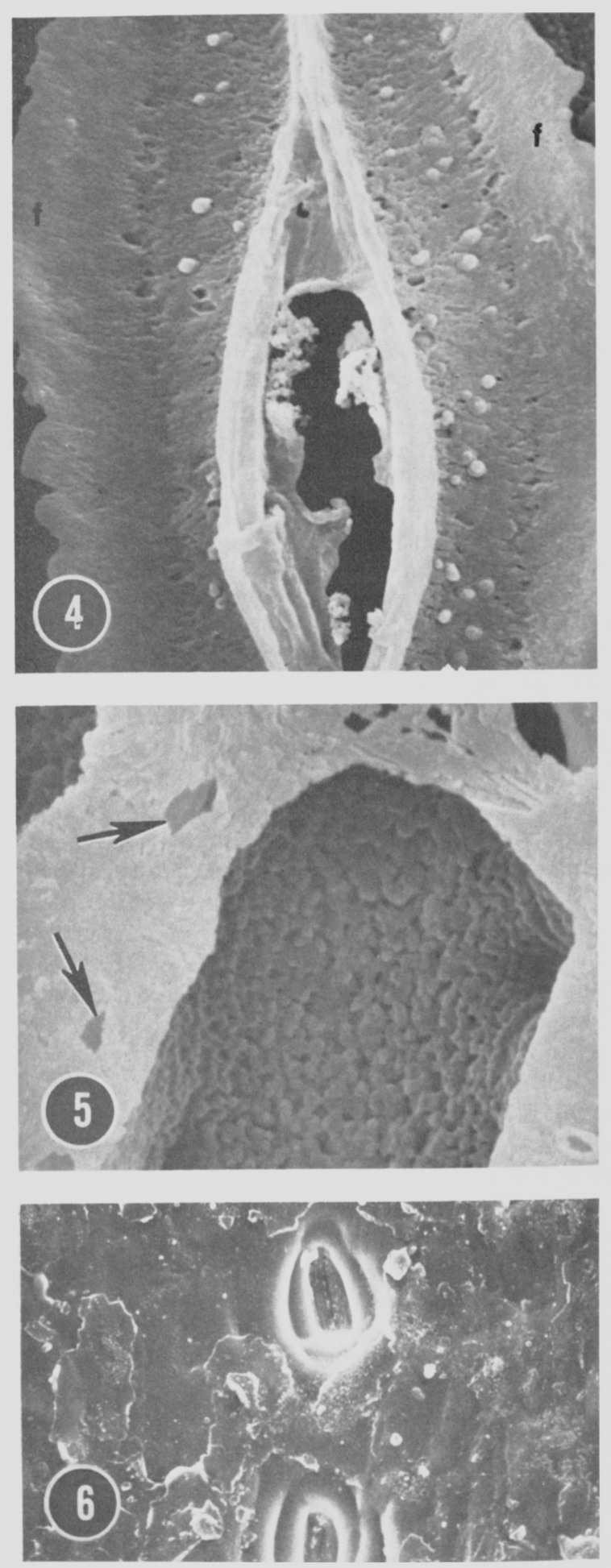

Figs. 1-6.-Araucaria angustifolia. Fig. 1, Lower cuticle, inner surface region of the stomatal apparatus, after 24-h treatment; $s c=$ subsidiary cell; $\times 1,000$. Fig. 2, Upper cuticle, inner surface after 24 -h treatment, $\times 100$. Fig. 3, Upper cuticle, outer surface showing cuticular plugs after 6-h treatment, $\times$ 500. Fig. 4, Lower cuticle, inner surface showing cuticle on guard cell surfaces after 24-h treatment; $f=$ flange between guard and subsidiary cells; $\times$ 4,000. Fig. 5, Lower cuticle, inner surface after 24-h treatment; arrows indicate pits; $\times 5,500$. Fig. 6, Upper cuticle, outer surface after 6-h treatment, showing three layers of cuticular thickening, $\times 450$. 

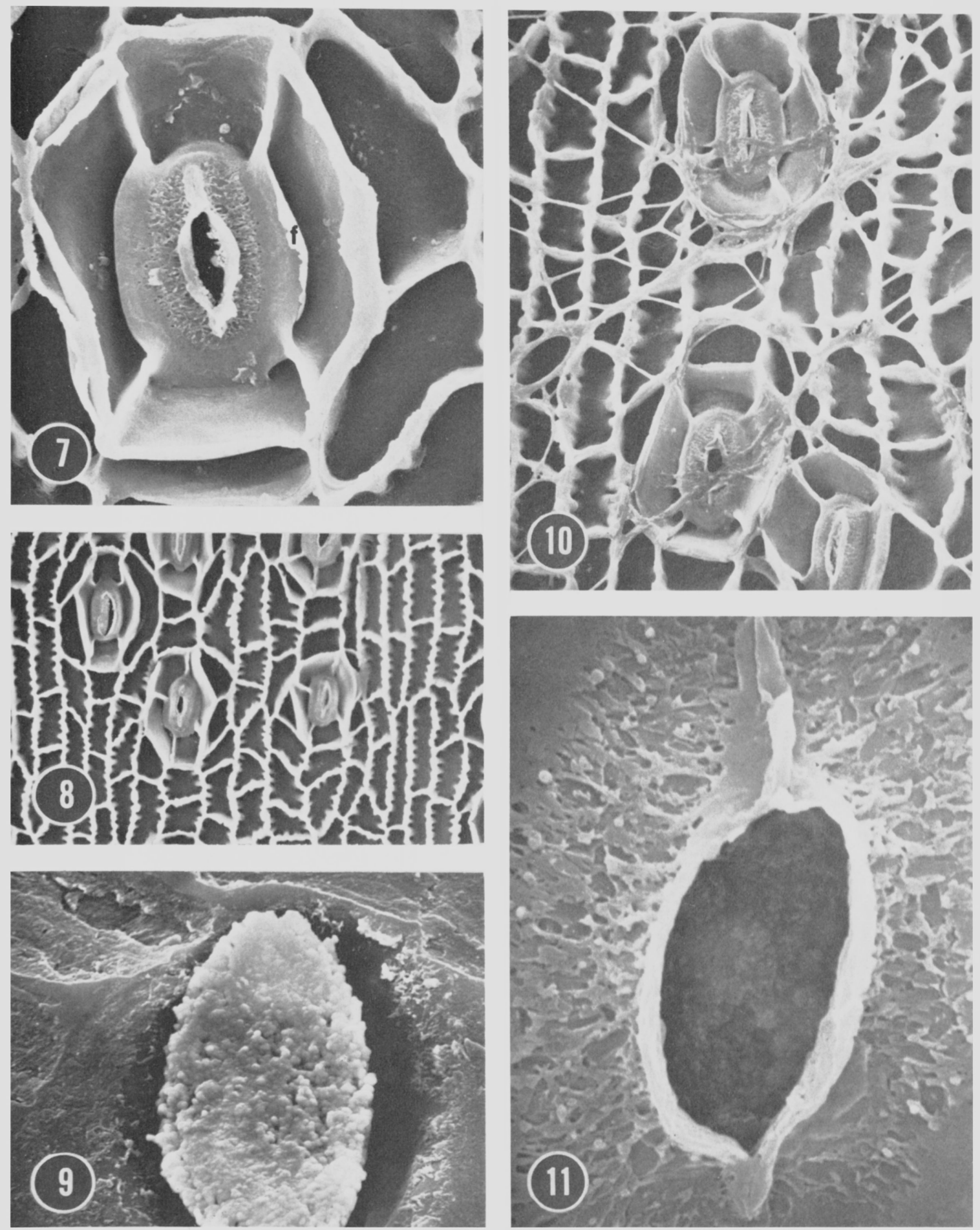

Figs. 7-11.-Araucaria klinkii. Fig. 7, Upper cuticle, inner surface, region of stomatal apparatus, after 24-h treatment; $f=$ flange between guard and subsidiary cells; $\times 1,000$. Fig. 8, Lower cuticle, inner surface after $24-\mathrm{h}$ treatment, $\times 250$. Fig. 9 , Cuticular plug on upper cuticle, outer surface after 24 -h treatment, $\times 1,500$. Fig. 10, Lower cuticle, inner surface after 18 -h treatment, $\times$ 500. Fig. 11, Upper cuticle, inner surface after 24 -h treatment, cuticle on guard cell surfaces, $\times 4,000$. 
types with a narrower attachment and nearly distichous arrangement on the branches. Both types of leaves were examined. The cuticle of $A$. bidwillii is thinner than that of $A$. angustifolia, but thick compared to other conifer genera. Externally, stomata occur in regular rows on both adaxial and abaxial surfaces of the smaller more imbricate leaves (fig. 16). There are few to no stomata on the adaxial surfaces of the larger leaves (fig. 17), while the lower surfaces have abundant regular rows of stomata. Externally, stomata have cuticular plugs. When the plug is removed (fig. 12), a raised area of cuticle becomes visible. This area is similar to but not as pronounced as the Florin rings described by Boulter (1971) in Pinus sylvestris L. or Podocarpus (BuchHolz and Gray 1948). Outlines of the epidermal cell walls are visible on the surface as slight depressions (figs. 12, 15).

The inner cuticle surface reveals rows of stomata with similarly oriented polar subsidiary cells. Subsidiary cell number, as in A. angustifolia, is four, rarely five, formed by both polar and nonpolar divisions. Intercellular flanges on epidermal cells are less steep than those of $A$. angustifolia and pitted (fig. 14). A 24-h treatment in chromium trioxide was necessary for $A$. bidwillii since leaves also have a system of hypodermal fibers (fig. 18). Epidermal cell walls are relatively straight, and the cuticle on these cell surfaces has a granular texture (fig. 13).

The guard cells of $A$. bidwillii are situated at the hypodermal level. Cuticle on the subsidiary cells is also umbrella shaped, as in $A$. angustifolia, but not as extensive between subsidiaries and epidermal cells (fig. 14). The surface of the cuticle on subsidiary cells is granular.

Flanges between guard and subsidiary cells have a smooth outline, unlike those of $A$. angustifolia (fig. 14). The surface of the ornamentation on guard cell walls has a reticulate-type pattern, as in A. klinkii, and the ridge of cuticular material between guard cells is similar to that in A. angustifolia with slight polar extensions (fig. 14).

Araucaria cunninghamit, Section Eutacta.Leaves, as in all species of Section Eutacta, are small, needlelike, and imbricate. Cuticle was studied for both mature and juvenile foliage. Mature leaves are more imbricate, broader based, and shorter, reaching about $1 \mathrm{~cm}$ long; immature leaves are more narrowly attached and may be over $2 \mathrm{~cm}$ long. Stomata on both leaf types occur in widely spaced rows on both adaxial and abaxial surfaces and possess cuticular plugs and levels of cuticular thickening like those of $A$. angustifolia (fig. 6).

The cuticle of $A$. cunninghamii is characterized by stomata that may be arranged either in regular rows or in a haphazard fashion (figs. 19, 20). Polar cells are usually oriented in one direction, but most stomata have slightly skewed guard cells (figs. 19,
20). This feature is even more pronounced than in A. klinkii (fig. 8). The number of subsidiary cells ranges from four to five; four is the common number (fig. 21), and five cells are the result of both polar and lateral subsidiary cell divisions (figs. 19, 20). The intercellular flanges on epidermal cells are steep and undulating with prominent buttresses (fig. 21). Bases of buttresses, like those of $A$. klinkii, show small striated ridges. Cell surfaces are smooth or contain small lens-shaped pits (fig. 21).

Guard cells are sunken to the hypodermal level, as in the other araucarian species (fig. 22). Araucaria cunninghamii, however, lacks the hypodermal fibers of $A$. angustifolia and $A$. bidwillii (fig. 22).

The umbrella-shaped cuticle covering the subsidiary cells is thinner than that in the other three araucarian species but is shallower and more extensive laterally. Subsidiary cells are wider than those of the other species (figs. 21, 22). The surface of the cuticle on subsidiary cells is smooth to pitted, as on the epidermal cells of this species. This portion of the cuticle sometimes has small wrinkles similar to those near the bases of epidermal cell buttresses. Flanges between guard and subsidiary cells are thin and smooth at the polar subsidiary cells and irregular in outline on lateral subsidiary cells (fig. 21). The surface ornamentation of guard cells is rough but not reticulate, as in A. bidwillii and A. klinkii, nor are there any small rounded bumps of cuticular material as in A. angustifolia. The ridge of cuticular tissue between the guard cells shows slight polar extensions (fig. 21) and is thicker than that found in the other three species.

Araucarites Santaecrucis.-The fossil leaves are preserved on some small twigs from the Cerro Cuadrado Petrified Forest. Although most of these have little internal anatomical preservation, externally there appear to be longitudinal striations on the abaxial surfaces of some specimens (STOckey 1977). CALDER (1953) suggested these striations might represent ribs of sclerenchyma or the position of lines of stomata. Scanning electron micrographs of the actual specimen surface indicate depressions, fairly regularly spaced and in linear rows (fig. 25). At higher magnifications (fig. 23), the outlines of cells may be seen together with depressions corresponding to the positions of sunken stomata. The positions of the stoma and guard cells can be outlined. Rubber replicas of the same surfaces show the details of epidermal cell shapes between the stomatal rows (figs. 24, 26). Buttresses on epidermal walls have been rounded by weathering and do not show the detail in living leaves (fig. 24). The stomata appear as bumps, and the outlines of the possible locations of subsidiary cells are indistinct. Cuticle of this type is typically gymnospermous and cannot be compared closely to those of living species except in gross morphology. Rows of sunken stomata are 

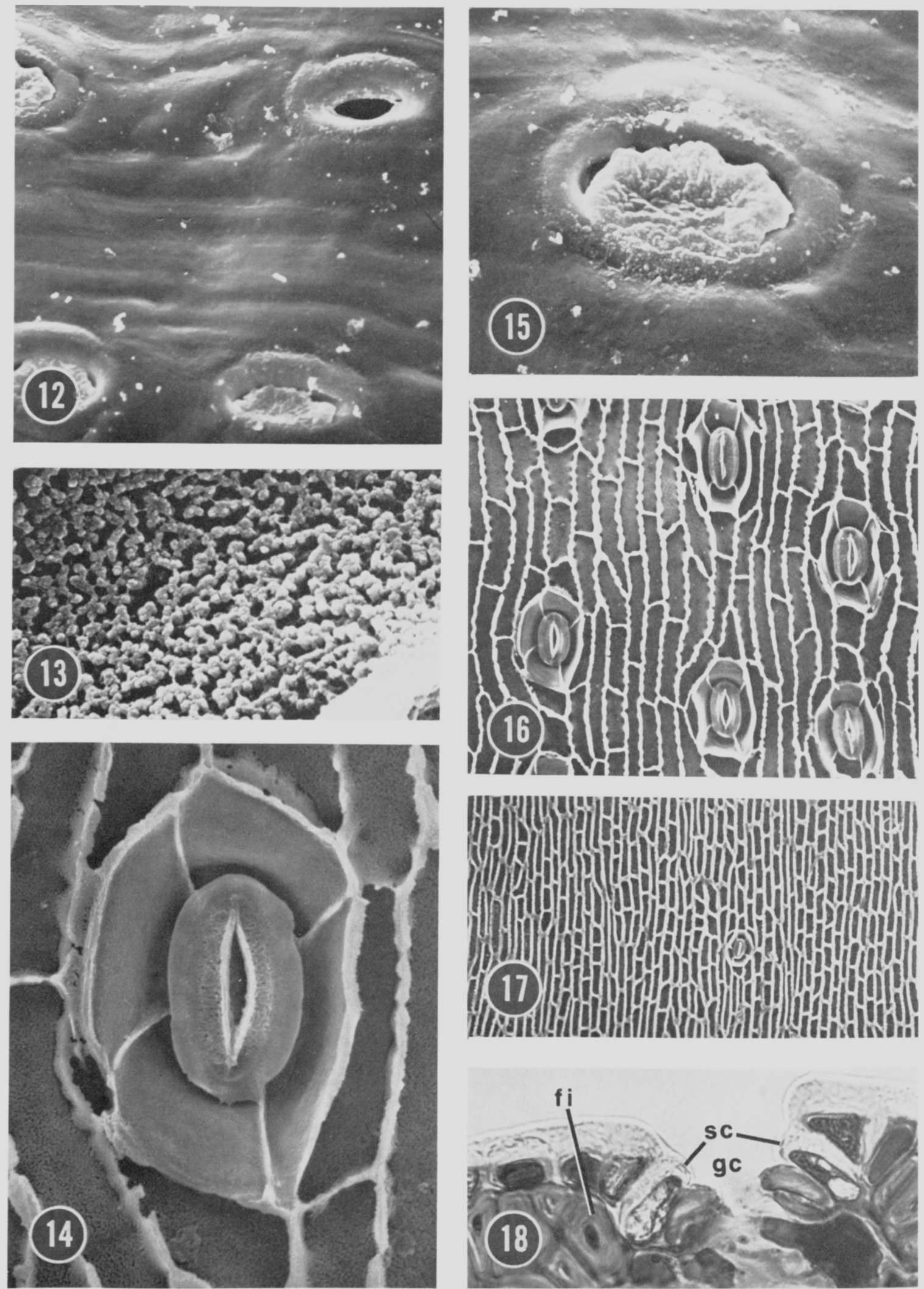

Figs. 12-18.-Arancaria bidwillii. Fig. 12, Lower cuticle, outer surface after 6-h treatment, showing cuticular plugs, raised areas, and indications of epidermal cells, $\times 500$. Fig. 13, Lower cuticle, inner surface after 24-h treatment, $\times 5,500$. Fig. 14, Imbricate leaf, upper cuticle, inner surface in region of stomatal apparatus after 24-h treatment, $\times 1,000$. Fig. 15, Lower cuticle, outer surface cuticular plug after 6-h treatment, $\times 1,000$. Fig. 16, Imbricate leaf, upper cuticle, inner surface after 24 -h treatment, $\times$ 250. Fig. 17, Large leaf, upper cuticle, inner surface after 24 -h treatment, $\times 100$. Fig. 18, Transverse section of leaf at stomatal apparatus; $f i=$ fibers, $g c=$ guard cells, $s c=$ subsidiary cells; $\times 700$. 
known to occur in the Cupressaceae, Araucariaceae, Cheirolepidaceae, Podocarpaceae, and Taxodiaceae (FLORIN 1931). The stomata are sunken singly in $A$. santaecrucis and are not situated in depressed rows. Fossil cuticular material with regular stomatal rows and singly sunken stomata includes: (Cheirolepidaceae) Frenelopsis varians (DAghlian and PERSON 1977), F. hoheneggeri (Watson and Alvin 1976); (Araucariaceae) Brachyphyllum mamillare (KENDALL 1949), Araucaria nathorstii (MENENDEZ and Caccavari 1966), Araucaria cutchensis (Pant and Srivastava 1968), B. macrocarpum (Hollick and Jefrerey 1906); Pagiophyllum ordinatum (Kendall 1948), P. connivens (Kendall 1948), P. insigne (Kendall 1948); (Taxodiaceae) Cryptomeria anglica (Alvin and Boulter 1974), Sequoia langsdorfii (Alvin and Boulter 1974); (Podocarpaceae) Podocarpus strzeleckianus, $P$. gnidioides, $P$. tasmanicus, $P$. totara (TownRow 1965).
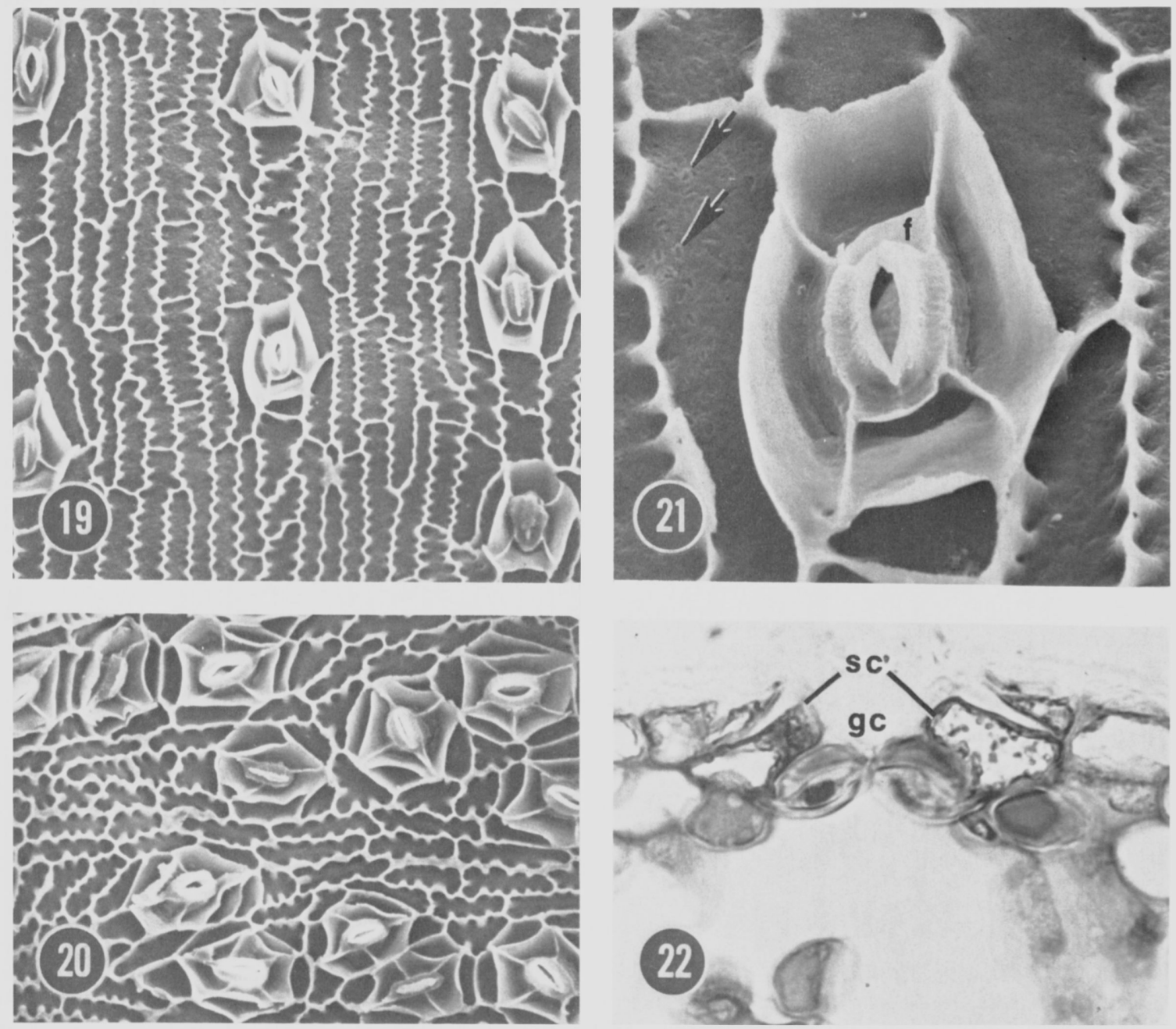

Figs. 19-22.-Araucaria cunninghamii. Fig. 19, Juvenile foliage, lower cuticle, inner surface after 24-h treatment, $\times 250$. Fig 20, Mature foliage, upper cuticle, inner surface after 24 -h treatment, $\times 250$. Fig. 21, Juvenile foliage, lower cuticle, inner surface in region of stomatal apparatus after 24-h treatment; $f=$ flange between guard and subsidiary cells; arrows indicate small lensshaped pits; $\times 1,000$. Fig. 22 , Cross section of leaf in region of stomatal apparatus; $g c=$ guard cells, $s c=$ subsidiary cells; $\times 700$. 
geographic location, and leaf morphology. White (1947) described three species native to New Guinea for which he erected a new section, Intermedia. These species, A. klinkii, A. schumanniana Warb., and A. hunsteinii K. Schum., had epigeal germination and winged cone scales, like the Eutacta species, and broad leaves as in Columbea. The latest revision of the genus Araucaria was done by WILDE and EAmes (1952); they erected a new section Bunya for the Australian A. bidwillii that has winged cone scales resembling Section Eutacta, hypogeal germi- nation like Section Columbea, and two foliar types unlike any other species. De Laubenfels (1972) suggested there are only two sections in the genus, Araucaria and Eutacta. Within the section Araucaria he includes the South American species A. angustifolia and $A$. araucana, the Australian $A$. bidwillii, and WhITE's (1947) Section Intermedia (A. klinkii, $A$. hunsteinii, and A. schumanniana). The other araucarian species are included within Section $E \boldsymbol{u}$ tacta, based on the differences between mature and juvenile foliage in these species. Based on the limited
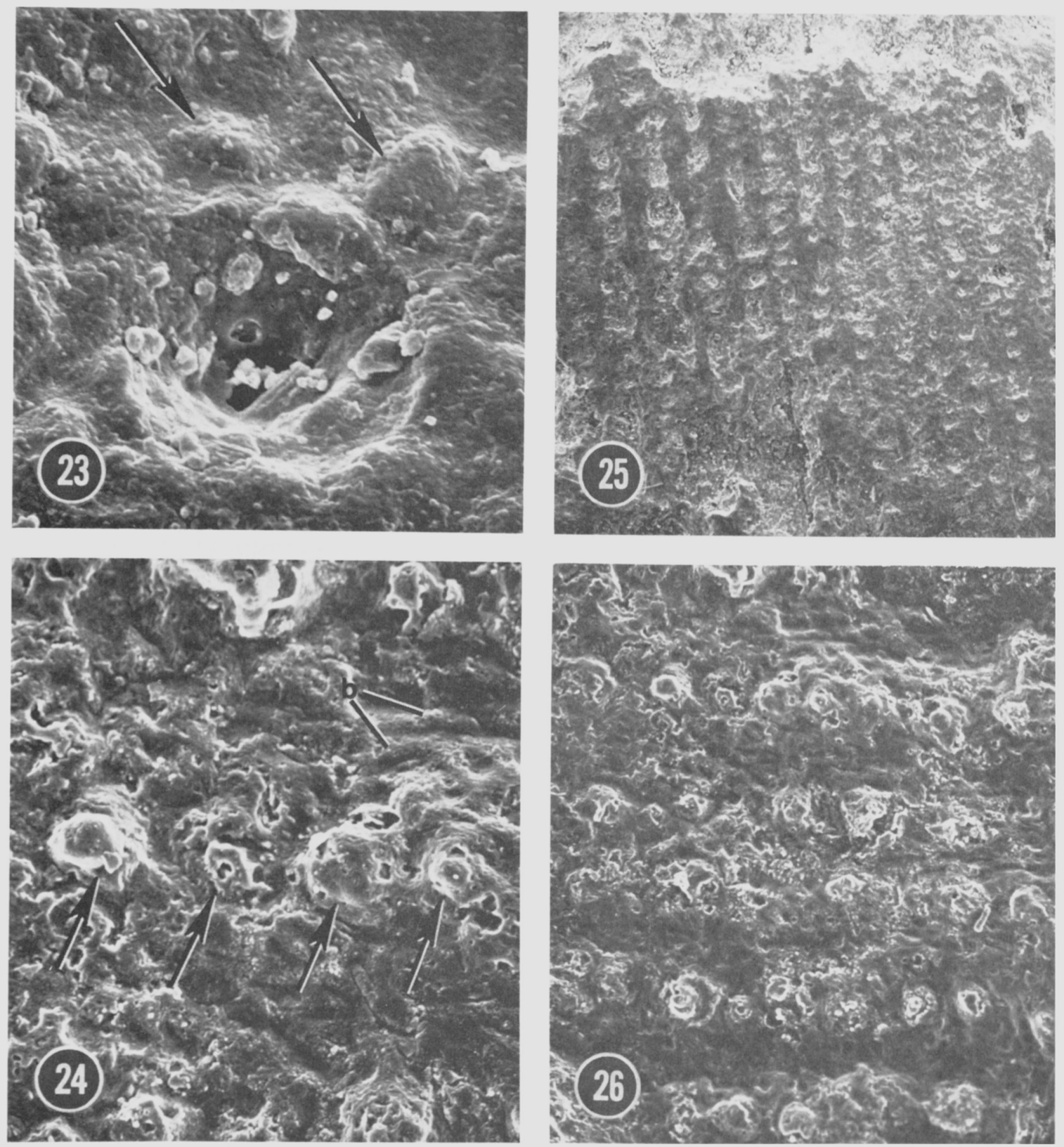

Figs. 23-26.-Araucarites santaecrucis. Fig. 23, Outer specimen surface showing depressed stoma and position of epidermal cells (arrows), $\times$ 720. Fig. 24, Rubber replica of adaxial surface showing raised areas corresponding to stomata (arrows) and depressions (epidermal cells); $b=$ epidermal cell cuticular buttresses; $\times 250$. Fig. 25, External surface of specimen showing regular rows of stomata, $\times 25$. Fig. 26 , Rubber replica of five regular stomatal rows and epidermal patterns, $\times 100$. 
number of species examined in this study, a division of the genus into two sections is suggested. The species assignments to these sections would differ from that of DE LAUBENFELS (1972), however.

Species of Columbea and Bunya have many cuticular features in common. The stomata are arranged in regular rows with the polar cells always oriented in the same direction. Numbers of subsidiary cells are generally constant at either four or five. The inner cuticular surface is granular on both epidermal and subsidiary cell surfaces. Holes or pits are present in the intercellular flanges.

The Eutacta and Intermedia species also share many cuticular features. The inner cuticular surface that covers subsidiary and epidermal cells is smooth with the exception of occasional lens-shaped pits in some $A$. cunninghamii leaves. Intercellular flanges are thinner in these two groups and exhibit a lower relief than the Columbea-Bunya species. The buttresses on epidermal cells are solid, lacking pits, and more sinuous in outline than the Columbea-Bunya species.
The cuticular features of the four species in this study are sufficiently distinct to permit each of them to be differentiated from the others. Study of the remaining species in the genus would, of course, be required to confirm the utility of such features in the genus as a whole. The results to date have been promising, and further study may well provide additional information of significant taxonomic value. In addition, these cuticular features may provide information of significant value in evolutionary considerations of this relict group of conifers.

\section{Acknowledgments}

We thank Dr. Eugene S. Richardson, Field Museum of Natural History, Chicago; Dr. BRITTA LundBLAd, Naturhistoriska Riksmuseet, Stockholm; Dr. Garth Nikles, Forestry Department, Brisbane; and Dr. Richard Gould and Mr. Ron Larson, Imbil Forestry Station, Queensland, for their assistance in obtaining the specimens used in this study. This work was supported in part by National Science Foundation grants BMS75-04221 and DEB77-02239.

\section{LITERATURE CITED}

Alvin, K. L., and M. C. Boulter. 1974. A controlled method of comparative study of taxodiaceous cuticles. J. Linnean Soc. Bot. $69: 277-286$.

Bose, M. N. 1975. Araucaria haastii Ettingshausen from Shag Point, New Zealand. Paleobotanist 22:76-80.

Boulter, M. C. 1971. Fine details of some fossil and recent conifer leaf cuticles. Pages 211-235 in V. H. Heywood, ed. Scanning electron microscopy: systematic and evolutionary applications. Academic Press, New York.

Buchiolz, J. T., and N. E. Gray. 1948. Taxonomic revision of Podocarpus. I. The sections of the genus and their subdivisions with special reference to leaf anatomy. J. Arnold Arboretum 29:49-63.

Calder, M. G. 1953. A coniferous petrified forest in Patagonia. Bull. Brit. Mus. Natur. Hist., Geol. 2:99-138.

Cookson, I. C., and S. L. Duigan. 1951. Tertiary Araucariaceae from southeastern Australia, with notes on living species. Australian J. Sci. Res. Melbourne, Ser. B, 4:415449.

Daghlian, C. P., and C. P. Person. 1977. The cuticular anatomy of Frenelopsis varians from the lower Cretaceous of central Texas. Amer. J. Bot. 64:564-569.

ENDlicher, S. 1842. Mantissa botanica sistens generum plantarum. Supplementum secundum, Vindobonae 26:26.

FEDER, N., and T. P. O'Brien. 1968. Plant microtechnique: some principles and new methods. Amer. J. Bot. 55:123-142.

FLORIN, R. 1931. Untersuchungen zur Stammesgeschichte der Coniferales und Cordaitales. Kunglica Svenska Vetenskapsakademiens Handlingar, Ser. 5, 10:1-588.

Hollick, A., and E. C. Jefrrey. 1906. Affinities of certain Cretaceous plant remains commonly referred to the genera Dammara and Brachyphyllum. Amer. Natur. 40:189-216.
Kendall, M. W. 1948. On six species of Pagiophyllum from the Jurassic of Yorkshire and southern England. Ann. Mag. Natur. Hist., Ser. 12, 1:73-108.

—. 1949. A Jurassic member of the Araucariaceae. Ann. Bot., N.S., $13: 151-161$.

Laubenfels, D. J. DE. 1972. Flore de la Nouvelle-Calédonie et dépendances. No. 4. Gymnospermes. Musée National Histoire Naturelle, Paris. 167 pp.

Menendez, C. A., and M. A. Caccavari. 1966. Estructura epidermica de Araucaria nathorsti Dus. de Terciario de Pico Quemado, Rio Negro. Ameghiniana 4:195-197.

Pant, D. D., and G. K. SRIvastava. 1968. On the cuticular structure of Arancaria (Arancarites) cutchensis (Feistmantel) comb. nov. from the Jabalpur series, India. J. Linnean Soc. Bot. 61:201-206.

Robison, C. F., and C. N. Miller, JR. 1975. Glycol methacrylate as an embedding medium for lignitic plant fossils. J. Paleontol. 49:559-561.

Stockey, R. A. 1977. The Cerro Cuadrado Petrified Forest (Jurassic) of Argentina: coniferous twigs and wood. Bot. Soc. Amer., Misc. Ser. Pub., 154:44. (Abstr.)

Townrow, J. A. 1965. Notes on some Tasmanian pines. I. Some lower Tertiary podocarps. Papers Proc. Roy. Soc. Tasmania 99:87-107.

Watson, J., and K. L. Alvin. 1976. Silicone rubber casts of silicified plants from the Cretaceous of Sudan. Palaeontology $19: 641-650$.

White, C. T. 1947. Notes on two species of Araucaria in New Guinea, and a proposed new section of the genus. J. Arnold Arboretum 28:259-260.

Wilde, M. H., and A. J. Eames. 1952. The ovule and 'seed' of Arancaria bidwilli with discussion of the taxonomy of the genus. II. Taxonomy. Ann. Bot., N.S., 16:27-47. 